\title{
フライアッシュを混和したモルタル中の鉄筋のさび
}

—ーンネルの中に放置した実験——

\begin{tabular}{|c|c|}
\hline 正 員 & $\equiv$ \\
\hline 正 員 & 杉 \\
\hline
\end{tabular}

\section{AN EXPERIMENT ON CORROSION OF REINFORCED STEEL IN FLY-ASH CEMENT MORTARS}

\author{
By Ichiro Miura, C.E. Member, and Rokuro Sugiki, C.E. Member
}

ySnopsis : This is an experiment to examine if the fly-ash admixed in mortar affects the growth or progress of the corrosion of reinforcing steel.

The properties of the mortar of specimens are as follows; proportion-1:3 1:5, water cement fly-ash ratio $(W / C+F)-58 \sim 103 \%$, replacement of cement with fly-ash $-0 \sim 60 \%$. These specimens had been stored for 32 months in a railway tunnel. From the test results, it may be suggested that the corrosion on embeded reinforcing steel is not induced easely unless the replacement with fly-ash exceeds $30 \sim 40 \%$ and $W / C+F$ is so large.

要 旨 セメントの一部をフライアッシュで置き換えたモルタル供試体をつくり, 中に鉄筋を埋込 み,フライアッシュの混和がさびの発生またはその進行に影響するかどうかを調べた。

用いたモルタルは，配合比 1:3〜1:5，水セメント比58１03\%，フライアッシュ置き換光率 0〜60 \%である。供試体はトンネル内に 2 年 8 月放置したのち, 中の鉄筋をとり出して調べた。

その結果は, フライアッシュ置き換光率が 30 40\%以下であって, 水対セメントフライアッシュ比 がいちじるしく大きくなければ，鉄筋のさびは容易に誘発されるものでないととを示唆するもののよう であった。

\section{1. 緒言}

コンクリートまたはモルタル中のセメントの一部をフライアッシュで置き換えると, 表面からの中性化の進行 が速くなり，そのため内部の鉄筋がさびるおそれが生じるともいわれている。そてで，種々の割合でセメントの 一部をフライアッシュで置き換えたモルタル供試体をつくり，中に鉄筋を埋込み，フライアッシュの混和がさび の発生またはその進行汇影響するかどうかを調べた。

\section{2. 供試体 製作}

\section{(1) 使 用 材 料}

使用した材料はつぎのとおりである。

セメント：N社 普通ポルトランド

フライアッシュ：U社

細骨 材: 相模川産砂, $1.2 \mathrm{~mm}$ ふるいでふるい, 粗粒を除いた。

鉄筋: 径 $6 \mathrm{~mm}$ 丸鋼, SS 41 , 表面はサンドペーパーで完全にみがきあげたのち, アセトンでよで れを妨いとった。

\section{（2）供試体の寸法およびモルタルの配合}

供試体の寸法は $40 \times 83 \times 160 \mathrm{~mm}$ で， 1 個の重量は約 $1.3 \mathrm{~kg}$ である。型わくには，JIS R 5201 セメント の強さ試験用型わくの隔板を 1 枚とりはずして用いた。埋込み鉄筋は 3 本とし，そのかぶりは供試体により 15 $\mathrm{mm}, 10 \mathrm{~mm}$, あるいは $5 \mathrm{~mm}$ とした（図一1）。

供試体は脱型後材令 14 日まで水中で養生し, 水中から取出して空気中に放置したのち現場に送った。供試体 の一部は，水中から取出した直後，曲げモーメントを与えて鉄筋を横断する方向にモルタルにひびわれをいれ 
た。とのひびわれの開口は $0.1 \sim 0.4 \mathrm{~mm}$ とな り鉄筋にまで達した。

モルタルの配合は，

（a）セメント+フライアッシュの単位量およ ぴモルタルのフローを一定としたもの，

(b) 水対セメント+フライアッシュ比および モルタルのフローを一定としたもの，

の 2 種とし, それぞれの配合についてフライア ッシュ置き換え率を変化した。

モルタルの練り混ぜおよび成型は, JIS R 5201 セメントの物理試験方法に準じて行なっ た。また, 各配合のモルタルは JIS R 5201 の 試験方法により材令 28 日の強度を試験した。

モルタルの配合, 強度, 鉄筋埋込み条件, お よび供試体番号は表一1に示す。供試 体の全数は 40 個となった。

\section{3. 実 験 方 法}

供試体は，所定のかぶりをもった面 を外面として, 下記トンネル内の待避 所に設置した（写真一1）。設置したと きのモルタルの材令は 21 35 日であ る。

設置筒所：東北本 線 塩釜トンネル $367.1 \mathrm{~km}$ の点。

トンネルの延長は $1220 \mathrm{~m}$ で, 列車 の通過のたびに供試体はかなりのばい 煙をとうむった。

このような状態で，ある期間放置し たのち，供試体を破壊して中の鉄筋を 取り出し,さびの発生状態を調べ る一方, モルタル破断面にフェノ ールフタレイン溶液を散布して中 性化の進行状態を調べた（写真一3 $\sim 19$ 参照)。

\section{4. 試 験 成 績}

\section{(1) 第 1 回調查結果}

現場設置後 5 カ月で調査した。

供試体表面はうすくばい煙でおおわれていた。結果は表一2のとおりである。この調査では，ひびわれをいれ た供試体の鉄筋は, いずれもひびわれ部分で, さびを発生してい た。ひびわれのない供試体では，5 そさびのてん跡が，25 亿さ びの発生が見られたが，その他の供試体ではさびの発生はなかっ た。

\section{(2) 第 2 回調查結果}

現場設置後 9 カ月で調査した。

結果は表一3のとおりである。第 2 回調査の供試体には，あら かじめひびわれをいれておいたものはない。水対セメントフラ
図-1 供試体の寸法
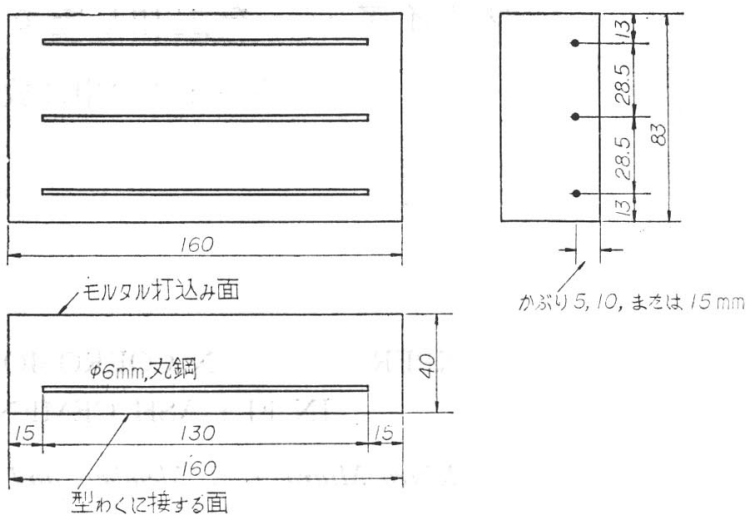

表一1 鉄筋を埋込んだモルタル供試体の製作条件

\begin{tabular}{|c|c|c|c|c|c|c|c|c|}
\hline \multicolumn{3}{|c|}{ モルタルの配合 } & \multirow{2}{*}{\multicolumn{2}{|c|}{$\begin{array}{l}\text { モルルの強度 } \\
\text { 材令 } 28 \text { 日, } \\
\mathrm{kg} / \mathrm{cm}^{2}\end{array}$}} & \multicolumn{4}{|c|}{ 鉄筋の埋込み条件 } \\
\hline \multirow{3}{*}{$C: F$} & \multirow{3}{*}{$\begin{array}{c}W / C+F \\
\%\end{array}$} & \multirow{3}{*}{$C+F / S$} & & & & bh & & $\begin{array}{l}\text { ひびわ } \\
\text { れあり }\end{array}$ \\
\hline & & & \multirow{2}{*}{ 曲 げ } & \multirow{2}{*}{ 压 縮 } & \multicolumn{4}{|c|}{ から゙り (mm) } \\
\hline & & & & & 15 & 10 & 5 & 10 \\
\hline
\end{tabular}

(a) $C+F$ 一定, フロー一定 $(170 \mathrm{~mm})$

\begin{tabular}{rr|c|c|c|c|c|rr|r|rr}
\hline 100 & 0 & 65 & $1: 3$ & 56.4 & 274 & 1,2 & 3,4 & 5,6 & 7,8 \\
80 & 20 & 64 & $"$ & 50.8 & 232 & & 9,10 & & \\
60 & 40 & 62 & $"$ & 37.4 & 147 & 11,12 & 13,14 & 15,16 & 17,18 \\
40 & 60 & 58 & $"$ & 22.9 & 97 & & 19,20 & & \\
100 & 0 & 110 & $1: 5$ & 21.3 & 61 & & 21,22 & & 23,24 \\
50 & 50 & 103 & $"$ & 11.7 & 34 & & 25,26 & & 27,28 \\
\hline
\end{tabular}

(b) $W / C+F$ 一定，フロー一定 $(170 \mathrm{~mm})$

\begin{tabular}{ll|l|l|l|l|l|l|l|l}
\hline 80 & 20 & 65 & $1: 3.05$ & 46.4 & 224 & & 29,30 & & 31,32 \\
50 & 50 & 65 & $1: 3.27$ & 27.3 & 101 & 33,34 & 35,36 & 37,38 & 39,40 \\
\hline
\end{tabular}

注：1） $C$ : セメント, $F$ : フライアッシュ, $S$ : 砂, $W$ : 水

2）鉄筋の埋込反条件の欄の数字は，供試体番号を示す。供試体は 1 組 2 個で，全数 は 40 個である。

写真-1 供 試 体 設 置 状態

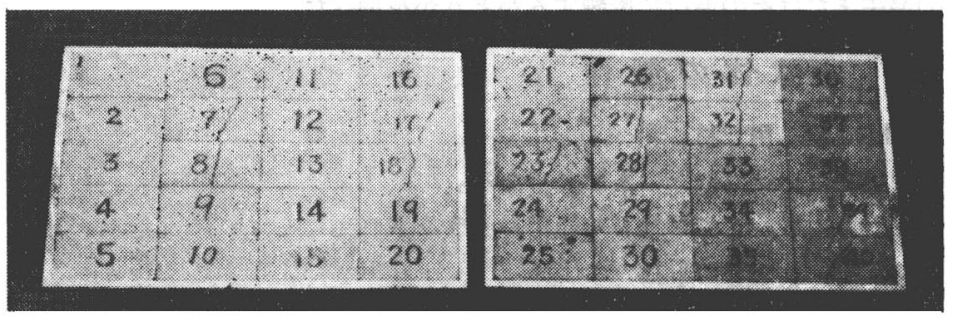


表一2 第 1 回 の調查 結 果

\begin{tabular}{|c|c|c|c|c|c|c|c|c|c|}
\hline $\begin{array}{l}\text { 供試体 } \\
\text { 番 号 }\end{array}$ & $\begin{array}{l}\text { フライアッ } \\
\text { 之ュ置高換 } \\
\text { 之率 }\end{array}$ & $\begin{array}{c}W / C+F \\
(\%)\end{array}$ & $\begin{array}{l}\text { か心价 } \\
(\mathrm{mm})\end{array}$ & $\begin{array}{l}\text { ひび } \\
\text { われ }\end{array}$ & 鉄 & 筋 & の & 状 & 態 \\
\hline 5 & 0 & 65 & 5 & なし & 3本とむわずかにさびのこん跡あり & & & & \\
\hline 7 & 0 & 65 & 10 & あり & ひびわれ筒所の鉄筋に長 $8 \sim 15 \mathrm{~mm}$, & 鉄筋周 & の約 & $1 / 2$ に & たりさび発生 \\
\hline 15 & 40 & 62 & 5 & なし & さびの発生なし & & & & \\
\hline 17 & 40 & 62 & 10 & あり & ひびわれ䇢所の鉄筋に長 $4 \sim 5 \mathrm{~mm}$, & 鉄筋周。 & の $1 ! 5$, & $-1 / 2$ & にわたりさび発生 \\
\hline 19 & 60 & 58 & 10 & なし & さびの発生なし & & & & \\
\hline 25 & 50 & 103 & 10 & なし & 3 本とも, 鉄筋の 1 端部に長 $11 \sim 37$ & $\mathrm{~mm}$, 金 & 鉄筋周 & の $1 / 2$ & にわたりさび発生 \\
\hline 37 & 50 & 65 & 5 & なし & さびの発生なし & & & & \\
\hline 39 & 50 & 65 & 10 & あり & ひびわれ䉪所の鉄筋に長 $8 \sim 12 \mathrm{~mm}$, & 鉄筋周 & 同の $1 /$ & $4 \sim 3 / 4$ & にわたりさび発生 \\
\hline
\end{tabular}

注:ひびわれの巾は $0.05 〜 0.1 \mathrm{~mm}$ であるが，開口部にはばい煙がつまっていた。

表一3 第 2 回 $の$ 調查 結 果

\begin{tabular}{|c|c|c|c|c|c|}
\hline $\begin{array}{l}\text { 供試体 } \\
\text { 番 号 }\end{array}$ & $\begin{array}{l}\text { フライアッジ } \\
\text { 置き換え率(\%) }\end{array}$ & $\begin{array}{c}W / C+F \\
(\%)\end{array}$ & $\begin{array}{l}\text { tisi? } \\
(\mathrm{mm})\end{array}$ & 鉄筋のさびの発生の有無 & $\begin{array}{l}\text { モルタルの中性华 } \\
\text { 露出面よりの中性化深さ }(\mathrm{mm})\end{array}$ \\
\hline 4 & 0 & 65 & 10 & な & な \\
\hline 6 & 0 & 65 & 5 & な & な \\
\hline 16 & 40 & 62 & 5 & な & な \\
\hline 22 & 0 & 110 & 10 & 3 本のうち2本さびのこん跡 & な \\
\hline 26 & 50 & 103 & 10 & 2 本は全長にわたり $1 / 2$ 周さび, 1 本は約 $1 / 2$ 長にわたり $1 / 2$ 周さび & $5 \sim 10 \mathrm{~mm}$ 中性化 \\
\hline 29 & 20 & 65 & 10 & な 2 & な L \\
\hline 35 & 50 & 65 & 10 & な & 1 3 mm 中性化 \\
\hline
\end{tabular}

イアッシュ比 $W / C+F$ のいちじるしく大きなモルタル中に埋めた鉄筋にはさびの発生を見た。さびの発生状態 は図一2 および 写真-2 のとおりで，鉄筋面でモルタル表面に近い方の側がさびている。

写真一2 フライアッシュ混和モルタルと鉄筋のさび

(トンネル内放置 9 カ月)

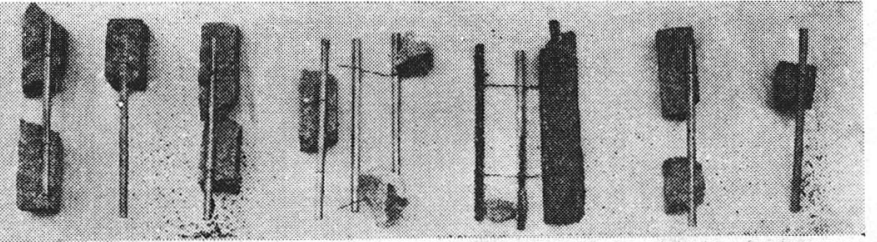

\begin{tabular}{|c|c|c|c|c|c|c|c|}
\hline 併試体番号 & 4 & 6 & 16 & 22 & 26 & 29 & 35 \\
\hline 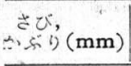 & ${ }_{1}{ }_{10}^{L}$ & $t_{5}{ }^{2}$ & ${ }^{1+5}{ }^{2}$ & $\begin{array}{l}\text { こん跡なし } \\
\text { ん跡 } \\
\quad 10\end{array}$ & 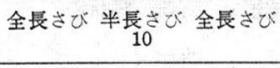 & ${ }_{10}^{2}$ & な $10^{2}$ \\
\hline$C / F$ & $100: 0$ & $100: 0$ & $60: 40$ & $100: 0$ & $50: 50$ & $80: 20$ & $50: 50$ \\
\hline$C+F / S$ & $1: 3$ & $1: 3$ & $1: 3$ & $1: 5$ & $1: 5$ & $1: 3.05$ & $1: 3.27$ \\
\hline$W \mid C+F(\%)$ & 65 & 65 & 62 & 110 & 103 & 65 & 65 \\
\hline 中性 化 & tक L & な & ts 2 & な & $\begin{array}{c}\text { 表面より } 5 \sim 10 \mathrm{~mm} \\
\text { 中 性 化 }\end{array}$ & な $L$ & $\begin{array}{c}\text { 表面よ) } 1 \sim 3 \mathrm{~mm} \\
\text { 中 性 化 }\end{array}$ \\
\hline
\end{tabular}

写真-3

(黒線でかこえだ内部がフェノールフタレーン
により着色したところ

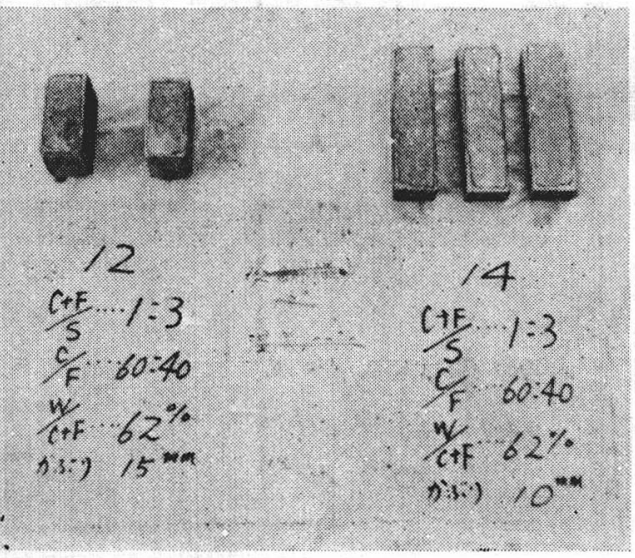

\section{写真-4} 24 および 0で，黒線でかこんだ部分がフェノー
ルフタレーンにより着色したところ，27，28 は
着色しない

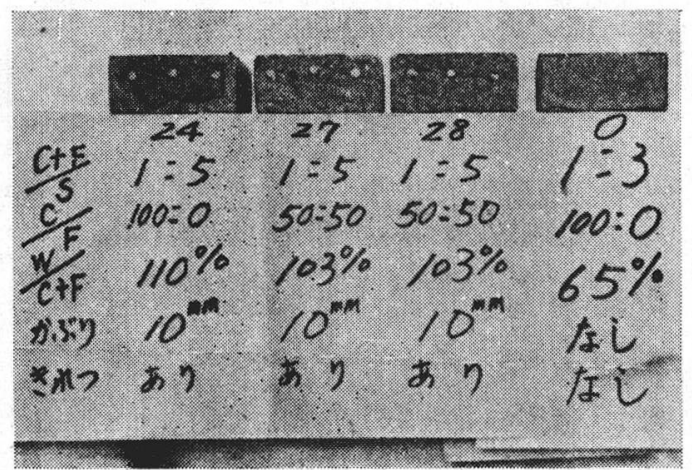


表一4 第 3 回 の 調 查 結 果

\begin{tabular}{|c|c|c|c|c|c|c|c|c|c|c|}
\hline \multirow{2}{*}{$\begin{array}{l}\text { 供試体 } \\
\text { 番 号 }\end{array}$} & \multirow{2}{*}{$\begin{array}{c}\text { フライア产シ } \\
\text { 置き換え率 } \\
(\%)\end{array}$} & \multirow[b]{2}{*}{$\begin{array}{c}W / C+F \\
(\%)\end{array}$} & \multirow{2}{*}{$\begin{array}{l}\text { からり } \\
(\mathrm{mm})\end{array}$} & \multirow{2}{*}{$\begin{array}{l}\text { ひ ひ } \\
\text { わ れ } \\
(\mathrm{mm})\end{array}$} & \multicolumn{3}{|c|}{ 鉄 筋 のさび } & \multicolumn{2}{|c|}{ 中性化深さ } & \multirow[b]{2}{*}{ ばく露されたモルタル面の状態 } \\
\hline & & & & & $\begin{array}{l}\text { さびの発 } \\
\text { 生してい } \\
\text { る本数 }\end{array}$ & $\begin{array}{c}\text { さびの巾 } \\
\text { 周 }\end{array}$ & $\begin{array}{l}\text { さびの長 } \\
\text { さ } \\
(\mathrm{mm})\end{array}$ & $\begin{array}{l}よ ゙ く \text { 露さ } \\
\text { れた面 } \\
\text { (mm) }\end{array}$ & $\begin{array}{l}\text { 反対側の } \\
\text { 面 } \\
(\mathrm{mm})\end{array}$ & \\
\hline 1 & 0 & 65 & 15 & なし & 0 & 0 & 0 & 0 & $0.5 \sim 2$ & \\
\hline 2 & $"$ & $"$ & 15 & $"$ & 0 & 0 & 0 & 0 & $0 \sim 2$ & \\
\hline 3 & $"$ & $"$ & 10 & $"$ & 0 & 0 & 0 & 0 & $0 \sim 1.5$ & \\
\hline 8 & $"$ & $"$ & 10 & 0.1 & 3 & $1 / 3$ & $24 \sim 52$ & 0 & $0 \sim 2$ & \\
\hline 9 & 20 & 64 & 10 & なし & 0 & 0 & 0 & $0 \sim 2$ & $1 \sim 2$ & \\
\hline 10 & " & " & 10 & $"$ & 0 & 0 & 0 & $1 \sim 5$ & $1 \sim 2.5$ & \\
\hline 11 & 40 & 62 & 15 & なし & 0 & 0 & 0 & $1 \sim 3$ & $3 \sim 4$ & \\
\hline 12 & $"$ & 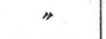 & 15 & " & 0 & 0 & 0 & $1 \sim 2$ & $1 \sim 2$ & \\
\hline 13 & $"$ & $"$ & 10 & $"$ & 0 & 0 & 0 & $0 \sim 3$ & $1 \sim 2.5$ & \\
\hline 14 & $"$ & " & 10 & " & 0 & 0 & 0 & $1 \sim 2$ & $1 \sim 2$ & \\
\hline 18 & $"$ & $"$ & 10 & 0.15 & 3 & $1 / 3$ & $15 \sim 32$ & $2 \sim 3$ & $1 \sim 3$ & \\
\hline 20 & 60 & 58 & 10 & なし & 3 & $1 / 5 \sim 1$ & 45～全長 & $8 \sim 14$ & $8 \sim 10$ & \\
\hline 21 & 0 & 110 & 10 & なと & 2 & $1 / 2 \sim 1$ & $17 \sim 21$ & $0 \sim 5$ & $2 \sim 8$ & \\
\hline 23 & $"$ & $"$ & 10 & 0.1 & 3 & $1 / 2 \sim 1$ & $45 \sim 68$ & $1 \sim 6$ & $1 \sim 6$ & \\
\hline 24 & $"$ & $"$ & 10 & 0.1 & 3 & $1 / 2 \sim 1$ & $10 \sim 22$ & $0 \sim 8$ & $3 \sim 10$ & \\
\hline 27 & 50 & 103 & 10 & 0.2 & 3 & 1 & 全 長 & 心まで & 心まて & 表面変色し, \\
\hline 28 & " & $"$ & 10 & 0.1 & 3 & 1 & 全 長 & 心まで & 心まで & ぼろほら \\
\hline 30 & 20 & 65 & 10 & なし & 0 & 0 & 0 & $0 \sim 1$ & $0 \sim 3$ & \\
\hline 31 & $"$ & $"$ & 10 & 0.2 & 3 & $1 / 3$ & $25 \sim 32$ & $0 \sim 1$ & $1 \sim 1.5$ & \\
\hline 32 & " & $"$ & 10 & 0.3 & 3 & $1 / 3$ & $15 \sim 17$ & $0 \sim 2.5$ & $1 \sim 1.5$ & \\
\hline 33 & 50 & 65 & 15 & なし & 1 & $1 / 2$ & 13 & $4 \sim 6$ & $4 \sim 8$ & 表面変色し, \\
\hline 34 & $"$ & $"$ & 15 & $"$ & 1 & $1 / 3$ & 39 & $4 \sim 7$ & $5 \sim 8$ & ぼろほらのものが多い \\
\hline 36 & $"$ & $"$ & 10 & $"$ & 1 & $1 / 3 \sim 1 / 2$ & 78 & $5 \sim 10$ & $5 \sim 8$ & \\
\hline 38 & $"$ & $"$ & 5 & $"$ & 2 & $1 / 3 \sim 1$ & $47 \sim 61$ & $5 \sim 10$ & $5 \sim 6$ & \\
\hline 40 & " & " & 10 & 0.1 & 3 & $1 ! 2 \sim 1$ & $29 \sim 76$ & $5 \sim 7$ & $8 \sim 14$ & \\
\hline
\end{tabular}

注：ばく露されたモルタルの面は, 全面にばい煙が付着していた。

写真一5

$\left.\begin{array}{l}\text { 黑線でかこえだ内部がフェノールフタレーン } \\ \text { こより着色したところ }\end{array}\right)$
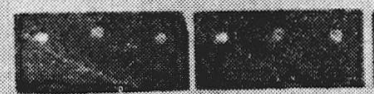

$31 \quad 32 \quad 40$

$\frac{C+F}{5} \quad 1=3.05 \quad 1: 3.05 \quad 1=3.27$

C.F 80:20 80:20 50:50

W

(j).3in $10^{\mathrm{m}} \cdot 10^{\mathrm{mm}} 10^{\mathrm{mm}}$

$x+2-5 \eta=2 y-5 \eta$

写真-6

同上

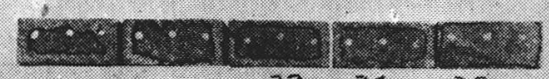

$20: 21: 33: 34: 30$

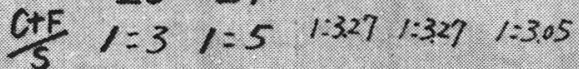

CFF $10-60$ 100:0 so:50 50:50 80:20

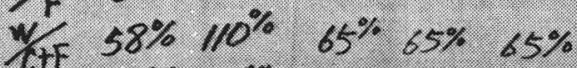

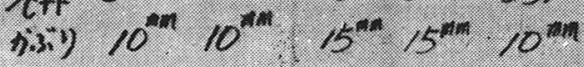

写真一7

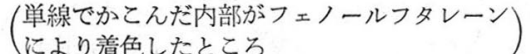

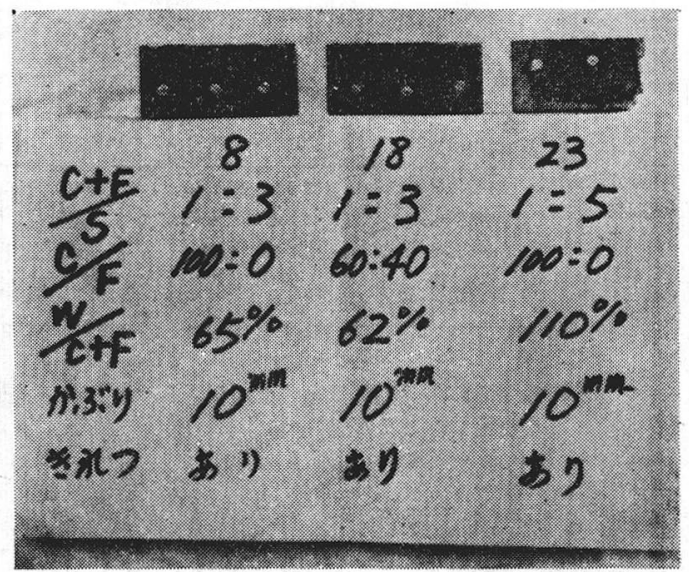

写真-8

同上

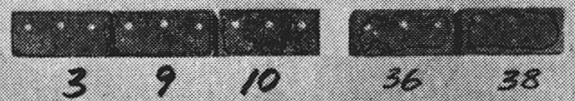

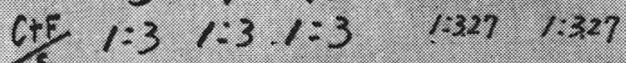

S. $100=0 \quad 80: 20 \quad 80=20 \quad 50=50 \quad 50=50$

$y=65 \% 64 \% 64 \%$. $65 \%$. $65 \%$

Ain: $10^{\text {min }} 10^{\text {min }} 10^{\text {min }} 10^{\text {min }}: 5^{\text {mm }}$ 
写真一9

黑線でかとえだ内部がフェノールフタレーンにより
着色したところ
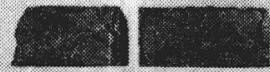

$\frac{\mathrm{ctE}}{\mathrm{s}} 1: 3 \quad \frac{2}{3} 1: 3 \quad 1: 3 \quad 1: 3$

CF 100:0 100:0 60:40 60:40

W + F $65 \% 65 \% 62 \% \quad 62 \%$

niviv $15^{\mathrm{mm}} 15^{\mathrm{mm}} 15^{\mathrm{mm}} 10^{\mathrm{mm}}$

\section{写真 -11}

$\left(\begin{array}{l}\text { 黑く見える部分がフェノールフタレーン } \\ \text { により着色したところ }\end{array}\right)$

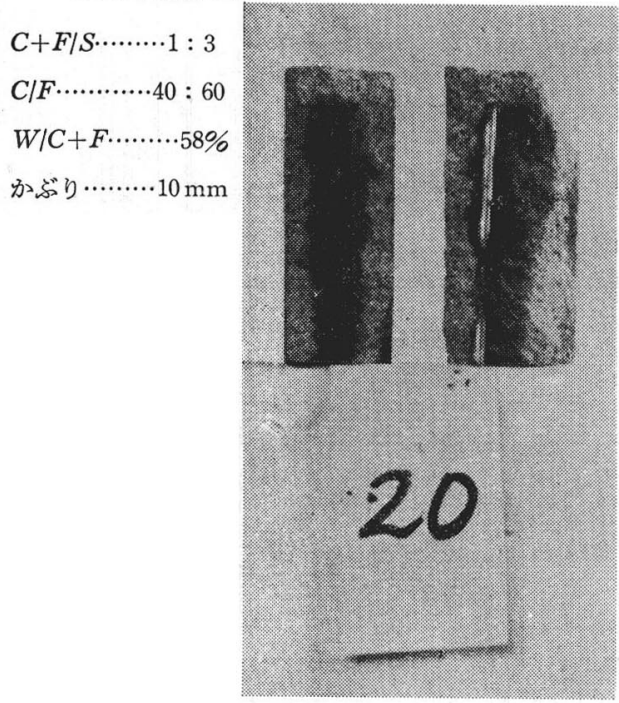

写真-13

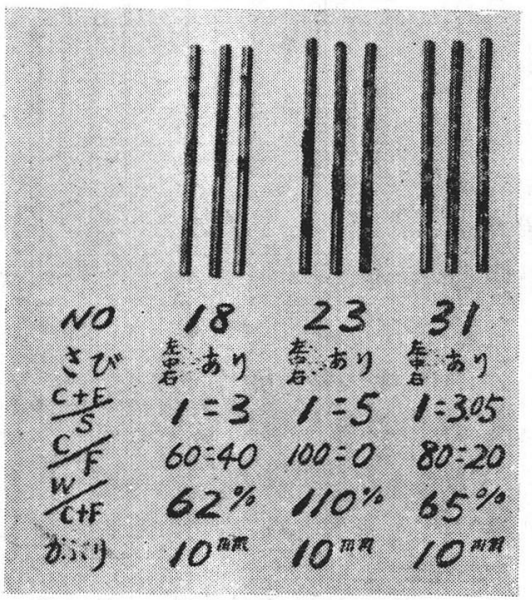

No $18 \quad 23 \quad 31$

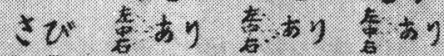

c $\frac{c+E}{s} \quad 1=3, t=5 \quad l=3.05$

c $\frac{5}{F} \quad 60: 40 \quad 100=0 \quad 80: 20$

w/F $62 \% 110 \% 65 \%$

bivin $10^{m m} 10^{m n} 10^{m n}$
写真-10

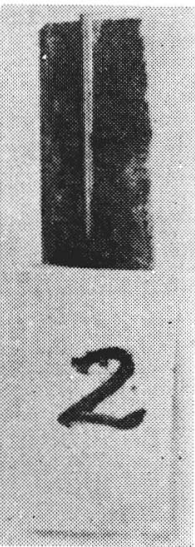

写真-12
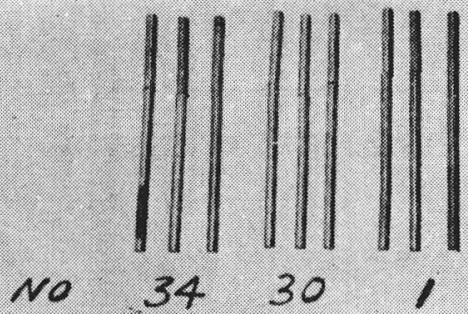

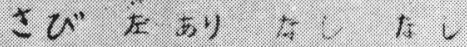

$\frac{c+5}{s} \quad=327 \quad 1-3.55 \quad l=3$

CF $50=50 \quad 80: 20 \quad 100=0$

w $+F \quad 65 \% 65 \% 65 \%$

Dis:y $15^{\mathrm{mm}} 10^{\mathrm{mm}}-15^{\mathrm{mm}}$

写真-14

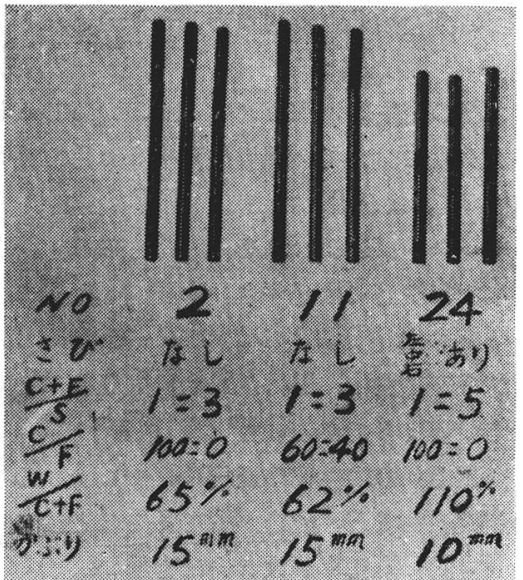

フェノールフタレイン溶液による中性化の調査結果では，フライアッシュ置き換光率 $50 \%$ のものに中性化の 進行が認められた。 


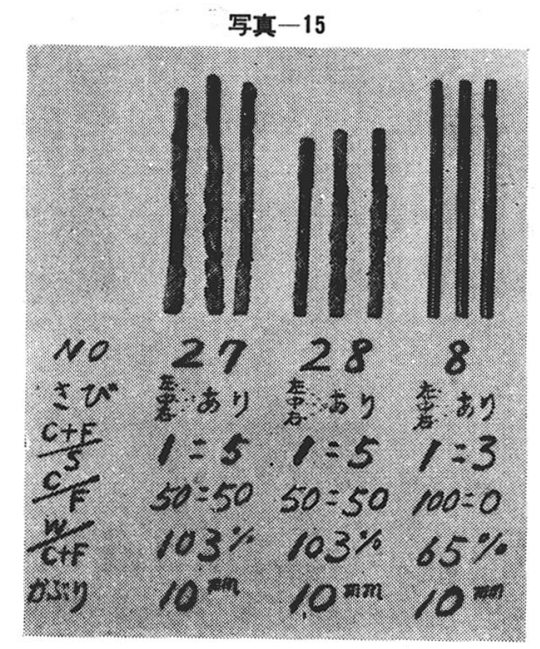

写真-17

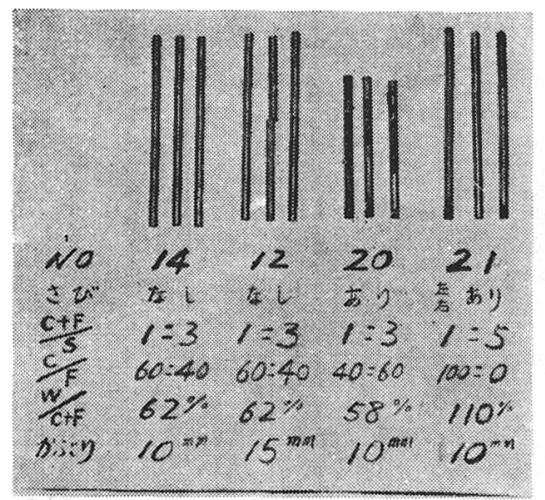

\section{（3）第 3 回調查結果}

現場設置後 2 年 8 カ月で, 残りの全供試体について 調查した。結果は表一4のとおりである。

さびの発生およびフェノールフタレーン散布による 変色の状態は写真一3 19 亿示す。

以上 3 回の調査結果を要約するとつぎのとおりであ る。

（1）さびの発生は, 水セメント比のいちじるしく 大きなモルタルにおいて, 現場放置後 9 力月で見られ た（供試体 22 および26)。

（2）モルタルにひびわれをいれたものは，ひびわ， れのところで, 鉄筋には必ずさびを発生した。

（3）ひびわれ部分以外の点におけるさびの発生 は, 表面からの中性化の進行が鉄筋に到達したととろ で起てっているようである。

（4）表面よりの中性化の進行は，モルタルの水セ メント比が大きいほど，配合が貧であるほど，またフ ライアッシュ置き換え率が大きいほど早い。

（5）フライアッシュ置き換え率が 40\%でも, 水セメント比が $62 \%$ のモルタル（供試体 11 18） は, 同じ 配合比で置き換え率 $0 \%$ \%ルタルにくらべ, 多少風化の進行は大きいようであるが, 鉄筋にさびを発生したも のはない。

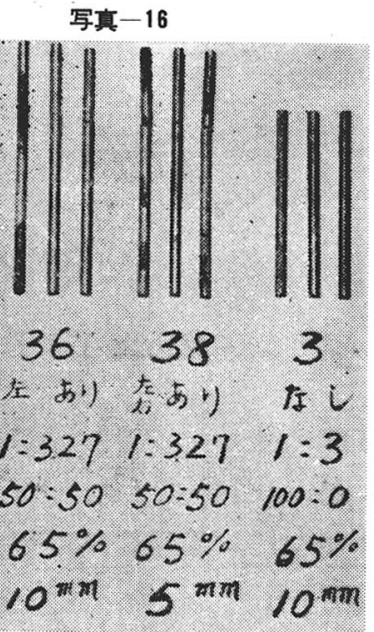

写真-18

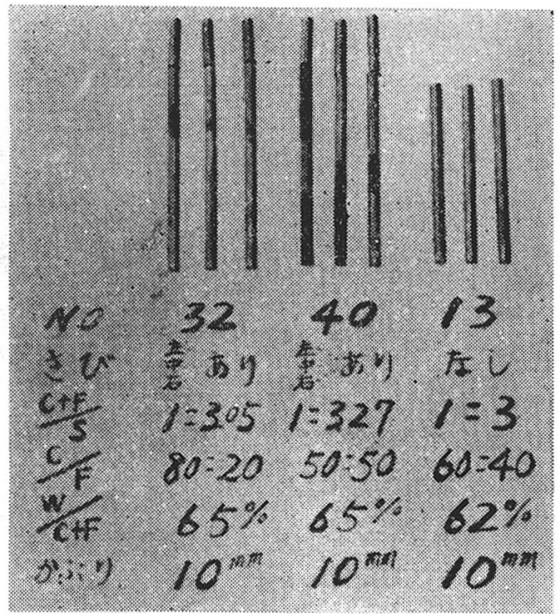

写真-19

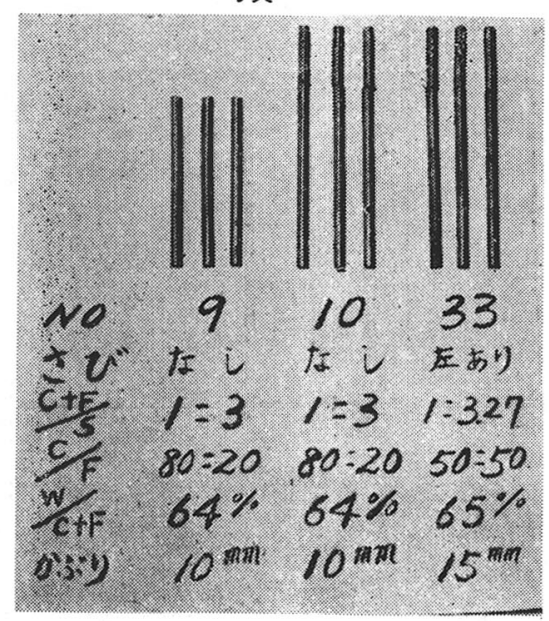




\section{5. 結言}

本実験の範囲においては，ての試験成績はセメントに対するフライアッシュの置き換え率が 30〜 40\% 以下で あり，水対セメントフライアッシュ比がいちじるしく大きくなければ，鉄筋のさびを誘発するものでないてと を示唆するものと思われる。

供試体にひびわれをいれたものでは, フライアッシュ混和の有無に関係なく、いずれもひびわれ部分で鉄筋に さびを生じた。てれにはトンネル内は相対湿度が大体 $90 \%$ 以上で，なおばい煙がてもるといったきわすて悪い 条件であったことを付記したい。

本実験は，トンネル内という特殊の場所におけるもので, 放置期間も長くないので, さらに条件を変光, 長期 にわたる実験を行ないたいと考えている。

終りにのぞみ，終始で指導下さった国分正胤先生に感謝の意を表する。 